\title{
ЗАДАЧІ ОПТИМІЗАЦІЇ КОМБІНОВАНИХ ЕНЕРГОСИСТЕМ ЗА ЕКОНОМІЧНИМИ КРИТЕРІЯМИ
}

\author{
М.П. Кузнєцов ${ }^{1}$, докт. техн. наук, О.В. Лисенко ${ }^{2}$, канд. техн.наук, О.А. Мельник ${ }^{3}$, аспірант. \\ ${ }^{1}$ Інститут відновлюваної енергетики НАН України, \\ 02094, вул. Гната Хоткевича, 20А, м. Київ, Україна. \\ ${ }^{2}$ Таврійський державний агротехнологічний університет, \\ 72310 , пр-т. Б. Хмельницького, 18, м. Мелітополь, Україна. \\ ${ }^{3}$ Національний технічний університет України «Київський політехнічний інститут ім. Ігоря Сікорського», \\ 03056, пр-т. Перемоги 37, м. Київ, Україна.
}

\begin{abstract}
Метою даної роботи є вирімення багатокритеріальної задачі оптимізачї для локальної енергосистеми (ЛЕС) 3 відновлюваними джерелами енергї (ВДЕ). В традиџійній енергетиці основною задачею є мінімізація собівартості електроенергії, але при застосуванні відновлюваних джерел енергії на перший план виступає надійність енергозабезпечення, враховуючи мінливу природу генерації таких ВДЕ, як вітрові та сонячні електростаниії. Предметом дослідження є пропориії вітрової, сонячної генерачії та систем зберігання енергії, що забезпечують задані вимоги до надійності при мінімальній собівартості електроенергії. Особливістю даного дослідження є врахування невизначеності режимів споживання та використання відновлюваних джерел енергії. Методи дослідження включають застосування статистичного підходу та імітаційне генерування випадкових процесів для стохастичної оптимізачії витрат. В якості вихідних даних використовуються історичні (статистичні) дані про споживання енергї та кліматичні фактори, які впливають на генерацію. Для показників надійності істотними є не лише середні значення, а й показники варіації (дисперсія, щільність розподілу, граничні відхилення). Невизначеність, пов'язана з відновлюваними джерелами, може призвести до невизначеності експлуатаиійних витрат. Додатковим джерелом невизначеностей $є$ змінний характер спожсивання електроенергії. Ризики проекту полягають в небезпеці втратити частину енергії чи не забезпечити потреби споживача. Наявність акумуляторів енергї̈ знижує ризики, але збільшує вартість проекту. Результатом дослідження $\epsilon$ спосіб оптимізації такої системи. Ризик можна визначити як дисперсію випадкової складової, тоді иільовими функціями будуть собівартість енергії та стандартне відхилення небалансу потужностей. Для пошуку оптимального рішення при двох критеріях застосовано математичну модель поточного стану енергосистеми з різнотипними ВДЕ та системою акумулювання. Огинаюча множини станів є лінією можливих оптимальних значень. Обмеженнями задачі $\epsilon$ вимоги до надійності, наприклад довірча імовірність небалансу генераиії та споживання. Бібл. 11, табл. 2, рис. 3.
\end{abstract}

Ключові слова: відновлювані джерела енергї̈, локальна енергосистема, надійність, собівартість, випадковий процес, оптимізачія.

\section{OPTIMIZATION TASKS OF THE COMBINED ENERGY SYSTEMS BY ECONOMIC INDICATORS}

\author{
M. Kuznietsov ${ }^{1}$, doctor of technical science, $\mathbf{O}$. Lysenko ${ }^{2}$, candidate of technical science, A. Melnyk ${ }^{3}$, graduate student. \\ ${ }^{1}$ Institute of Renewable Energy of the National Academy of Sciences of Ukraine, \\ 02094, 20A Hnata Khotkevycha St., Kyiv, Ukraine. \\ ${ }^{2}$ Tavria State Agrotechnological University, \\ 72310, 18 B. Khmelnitskoho Av., Melitopol, Ukraine. \\ ${ }^{3}$ National Technical University of Ukraine "Igor Sikorsky Kiev Polytechnic Institute", \\ 03056, 37 Peremohy Av., Kyiv, Ukraine.
}

The purpose of the paper is to solve a multicriteria optimization problem for a local energy systems (LES) with renewable sources (RES). The primary objective of traditional energy is to minimize the cost of electricity, but in case of renewable energy systems the reliability of energy is at the forefront, given by changing nature of the RES generation, such as wind and solar power. The subject of the study is the proportions of wind, solar generation and energy storage systems, which provide the set requirements for reliability with minimal cost of electricity. A feature of this study is the consideration of uncertainty in the modes of consumption and use of renewable energy sources. Research methods include the application of a statistical approach and the simulation of random processes for stochastic optimization. Historical (statistical) data on energy consumption and climatic factors that influence generation are used as input. Not only average values but also variance indicators (variance, distribution density, marginal deviations) are significant for reliability indicators. Uncertainty related to renewables can lead to uncertain operational costs. An additional source of uncertainty is the variable nature of electricity consumption. The risks of the project are the danger of losing some of the energy or not meeting the needs of the consumer. Having energy accumulators reduces the risks, but adds to the cost of the project. The result of the study is a way to optimize such a system. Risk can be defined as the variance of a random component, then the target functions will be the cost of energy and the standard deviation of the power imbalance. To find the optimal solution under two criteria, a mathematical model of the current state of the system with different RES and accumulation system was applied. The envelope of the multiple states is the line of possible optimal values. The limitations of the task are the requirements for reliability, such as the confidence probability of an generation and consumption imbalance. Ref. 11, tab. 2, fig. 3 .

Keywords: renewable energy, local energy system, reliability, cost, random process, optimization.

(C) М.П. Кузнєцов, О.В. Лисенко, О.А. Мельник, 2019

Відновлювана енергетика. 2019. № 4 


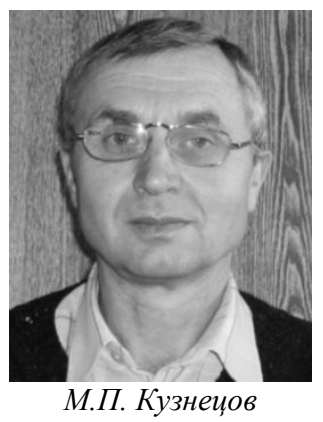

M. Kuznietsov

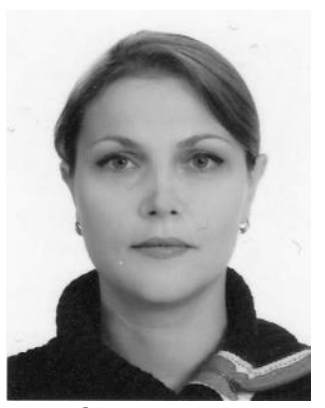

O.В. Лисенко

O. Lysenko

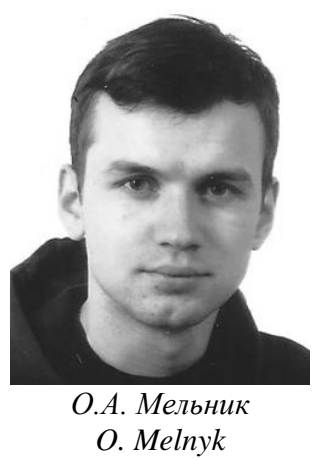

Відомості про автора: заступник директора Інституту відновлюваної енергетики НАН України, доктор технічних наук.

Освіта: Київський державний університет

ім. Т. Шевченка, механіко-математичний факультет.

Наукова сфера: математика, відновлювана енергетика.

Публікації: понад 70.

ORCID: 0000-0002-0497-7439.

Контакти: тел./факс: +38 (044) 206-28-09.

e-mail: renewable@ukr.net

Відомості про автора: доцент кафедри енергетики та автоматизації Таврійського державного агротехнологічного університету, доцент, кандидат технічних наук.

Освіта: Таврійська державна агротехнічна академія, енергетичний факультет.

Наукова сфера: електропостачання, відновлювана енергетика.

Публікації: понад 40.

ORCID: 0000-0001-7085-7796.

Контакти: тел.: +38 (061) 942-06-18.

факс: +38 (061) 942-24-11.

e-mail: office@tsatu.edu.ua

Відомості про автора: аспірант, інженердослідник

Освіта: Національний технічний університет

України «Київський політехнічний інститут

ім.І.Сікорського», факультет

електроенерготехніки та автоматики

Наукова сфера: електроенерготехніка,

відновлювана енергетика.

Публікації: 7 .

ORCID: 0000-0003-2894-3476.

Контакти: тел./факс: +38(044) 236-21-49.

e-mail: aspirantura@kpi.ua
Author information: Deputy Director of the Institute of Renewable Energy of the NASU,

Doctor of technical sciences.

Education: Taras Shevchenko Kyiv State

University, Faculty of Mechanics and

Mathematics.

Research area: mathematics, renewable energy.

Publications: over 70.

ORCID: 0000-0002-0497-7439.

Conatacts:tel./fax: +38 (044) 206-28-09.

e-mail: renewable@ukr.net

Author information: Associate Professor, Department of Energy and Automation Tavtia State Agrotechnological University, Associate Professor, Candidate of Technical Sciences.

Education: Tavria State Agrotechnical

Academy, Energy.

Research area: power supply, renewable energy.

Publications: over 40.

ORCID: 0000-0001-7085-7796.

Contacts: tel.: +38 (061) 942-06-18.

fax: +38 (061) 942-24-11.

e-mail: office@tsatu.edu.ua

Author information: graduate student, research engineer

Education: National Technical University of Ukraine "Igor Sikorsky Kyiv Polytechnic Institute", Faculty of Electric Power Engineering and Automatics.

Research area: electric power engineering, renewable energy.

Publications: 7 .

ORCID: 0000-0003-2894-3476.

Contacts: тел./факс: +38(044) 236-21-49.

e-mail: aspirantura@kpi.ua

Перелік використаних позначень та скорочень:

ВДЕ - відновлювані джерела енергії;

ВEC - вітрова електростанція;

CEC - сонячна електростанція;

АКБ - акумуляторна батарея;

Cв - собівартість;

$D$ - дисперсія;

Вступ. Головною економічною умовою при побудові локальної енергосистеми (ЛЕС) виступає, як правило, мінімізація собівартості електроенергії. Однак у випадку застосування відновлюваних джерел енергії (ВДЕ) важливою $\epsilon$ надійність енергозабезпечення, враховуючи мінливу природу генерації таких ВДЕ, як вітрові (BEC) та сонячні (СЕС) електростанції. Якщо показником надійності виступають індекси втрати енергії чи споживання (LOLP, LOLE, тощо) [1], то фізичним іх вираженням може слугувати дисперсія значень генерованої потужності (для довільного споживача) або результуючого небалансу енергії (у випадку заданого режиму споживання). Економічним вираженням небалансу є вартість балансуючих (резервних та/або акумулюючих) потужностей, пропорційних стандартному відхиленню.

Енергетичні потреби ЛЕС задовольняються за допомогою комплексу на базі відновлюваної енергетики (фотоелектричні та вітрові установки), автономної керованої генерації (дизель-генератор та ін.), засобів акумулювання енергіï, централізованої електромережі. Компонування такої енергосистеми передбачає дотримання певних вимог щодо балансової надійності. В якості вихідних даних до економічної оцінки ВДЕ у складі локальної енергосистеми зазвичай використовуються історичні (статистичні) дані про споживання та 
кліматичні фактори, що сприяють відновлюваній генерації, при цьому фіксуються погодинні середні дані та їх стандартні, тобто середньоквадратичні відхилення (СКВ), див. наприклад [2]. Особливістю даного дослідження, на відміну від традиційних робіт, є включення невизначеності споживання та виробництво електроенергії з відновлюваних джерел енергії, застосування статистичного підходу та імітаційне генерування випадкових процесів для стохастичної оптимізації витрат на енергозабезпечення ЛЕС.

В якості цільової функції для оптимізації гібридної енергосистеми здебільшого розглядають вартісну складову, тобто цільова функція $€$ сумою всіх чистих теперішніх вартостей. Це може бути мінімізація вартості обладнання (детермінований критерій); якщо критерієм є собівартість електроенергії, то цільова функція має вигляд:

$$
f\left(c_{i}, T\right)=\int_{0}^{T} \sum_{i}^{N} c_{i} y_{i}(t) d t \rightarrow \min ,
$$

де $c_{i}$ - питома вартість одиниці електричної енергії від $i$-го генеруючого елемента (чи групи елементів певного типу); $y_{i}(t)$ - обсяг електричної енергії, отриманої від $i$-го елемента; $N$ - кількість елементів; $T$ - час експлуатації.

В загальному випадку вартості елементів мають включати капітальні витрати, демонтаж, поточну експлуатацію та технічне обслуговування.

Оскільки однією 3 цілей відновлюваної енергетики $€$ зменшення витрат традиційного палива та екологічна безпека, одним 3 критеріїв має бути збільшення частки ВДЕ, а до витрат відносять також екологічну складову, тобто вартість компенсації шкідливих викидів. Що стосується обмежень, то їх складову в частині надійності можна виразити в термінах допустимих коливань небалансу [3], або ж мінімізацію небалансу вважати одним 3 критеріїв.

Постановка завдання. В загальній постановці вартісні показники замінюються в часі. При заміні змінних показників їх математичним сподіванням, тобто переходу до осереднених значень, задача оптимізації стає детермінованою і в переважній кількості досліджень саме так і вирішується. Однак для показників надійності істотним $\epsilon$ не лише середнє значення генерації та споживання (тобто енергобалансу), а й показники їх варіації (дисперсія, щільність розподілу, граничні відхилення) [4].
Система 3 відновлюваними джерелами енергії має бути спрямована на зменшення вартості (власне собівартості) електроенергії за рахунок оптимального підбору характеристик обладнання. Однак невизначеність, пов'язана 3 відновлюваними енергетичними ресурсами, може спричинити ненадійне виробництво електроенергії, що в свою чергу призведе до невизначеності експлуатаційних витрат. Додатковим джерелом невизначеностей $\epsilon$ змінний характер споживання електроенергії. Таким чином, експлуатаційні витрати на виробництво електроенергії можуть бути досить непередбачуваними. Тому потрібен статистична аналіз, що включає оцінку стохастичності процесів, оскільки детермінований розрахунок може дати помилкове уявлення про ймовірні витрати та потенційну економію.

Оскільки імовірнісна природа ВДЕ обумовлює ризик залишитися без достатнього енергопостачання або істотно знижує надійність останнього, виникає проблема виміру ризику i його впливу на вартість енергії [5]. Природною реакцією на наявність ризику $\epsilon$ прагнення використовувати одночасно різні види енергії диверсифікувати обладнання ВДЕ. Зі збільшенням числа елементів (обладнання ВДЕ) зменшується загальний розмір ризику. Інший шлях ослаблення впливу ризику полягає в управлінні ризиком. Це можливо, наприклад, за допомогою розрахунку співвідношення встановлених потужностей кожного з видів ВДЕ. Однак тільки коли ризик може бути оцінений у вигляді статистичного показника, управління ризиком отримує надійне обгрунтування. При статистичному аналізі ризик часто вимірюється за допомогою такої стандартної характеристики, як дисперсія чи пов'язане 3 нею середньоквадратичне відхилення. Оптимізація за показником СКВ розглядалася зокрема в [3]. Поточні значення небалансу генерації та споживання електроенергії, як відхилення від графіка навантаження, можуть бути описані у вигляді:

$$
p_{i j}=\left(a_{i j}-a_{i}\right)-\left[\left(w_{i j}-w_{i}\right)+\left(s_{s j}-s_{i}\right)\right],
$$

де $a_{x}$ - рівень споживання електроенергії; $w_{x}$ та $s_{x}$ - потужність ВЕС та СЕС відповідно; $i$ - індекс часу (в даних прикладах крок 30 хв.); $j$ - номер доби.

Дана характеристика визначає імовірні відхилення від середніх значень. Чим вони більші, тим вище розсіювання показників навколо середнього i, отже, значнішим є ступінь ризику. Перевагою СКВ є те, що при близькості 
реального розподілу до нормального цей параметр може бути використаний для визначення меж, в яких із заданою вірогідністю слід очікувати значення випадкової змінної, в нашому випадку небалансу потужностей [6]. Зазначимо також важливість врахування кореляції різних процесів. Тоді другою цільовою функцією, поряд з собівартістю енергії (1), буде дисперсія небалансу потужностей:

$$
\sigma_{\Sigma}^{2}=D\left(p_{i j}\right) \rightarrow \min .
$$

Якщо говорити про двокритеріальну оптимальність конфігурації ЛЕС, то собівартість отриманої 3 ВДЕ електроенергії має порівнюватися 3 альтернативним безризиковим джерелом (електромережею для комбінованих систем чи керованим джерелом типу дизельгенератора в автономних системах). Графічна інтерпретація пошуку оптимального рішення зображена на рис. 1, де застосовано математичну модель Дж.Тобіна (див. $[5,7])$ :

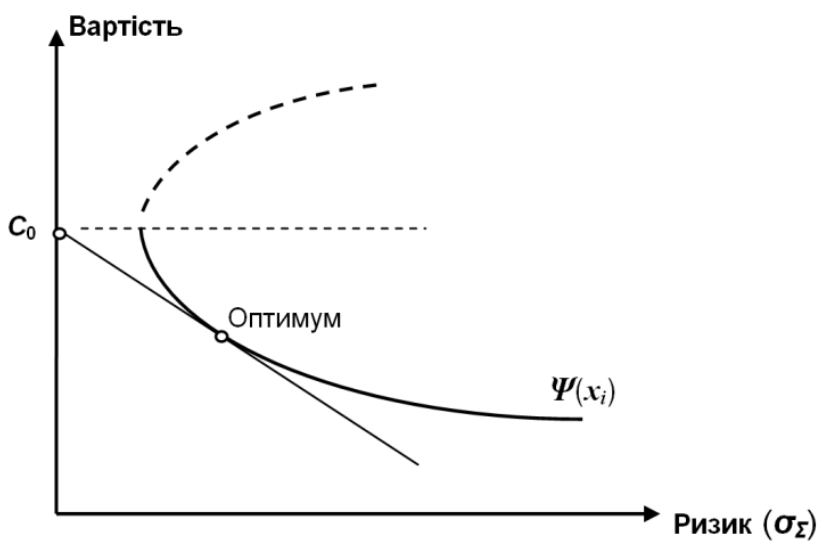

Рис. 1. Інтерпретація пошуку оптимальної конфігурації ЛЕС.

Fig. 1. Interpretation of the LES optimal configuration finding.

Точки кривої $\Psi\left(x_{i}\right)$, що є огинаючою області значень стану ЛЕС, задаються вектор-функцією $\Psi\left(w, \quad R, \quad k_{w}, \quad k_{s}, \quad \sigma_{\Sigma}, \quad \sigma_{\max } \ldots\right)$, який описує конфігурацію та стан ЛЕС $з$ різнотипними ВДЕ (аналог кривої ризику-доходу Марковіца [8], але задача на мінімум вартості, а не максимум доходу). Тут параметри кривої стану $\Psi\left(x_{i}\right)$ стосуються певної конфігурації ЛЕС та показників енергетичної ефективності окремих ВДЕ, наприклад: $w$ - пропорція потужностей BEC та CEC, $R$ - сумарна потужність ВДЕ, $k_{w}$ та $k_{s}-$ коефіцієнти використання встановленої потужності $\left(K_{\text {Ввп }}\right)$ ВЕС та СЕС, $\sigma_{\Sigma}-\mathrm{CKB}$ сумарного небалансу, $\sigma_{\max }-$ допустима СКВ, тощо. Сама функція визначає вартість генерованої електроенергії та рівень ризику як дисперсію відносно середніх значень. Якщо через $C_{0}$ позначити точку безризикової вартості, то оптимальною буде конфігурація ЛЕС, що відповідає точці «Оптимум» (рис.1), отриманій через дотичну з точки $C_{0}$ до кривої стану (модель оптимального фінансового портфеля по Дж.Тобіну) [7]. За означенням це задача опуклого програмування, яка розв'язується стандартними методами. В такій постановці вважається, що більш дешеві конфігурації мають вищий ступінь ризику. Це дещо суперечить тому факту, що енергія ВДЕ в даний час дорожча, ніж отримана 3 електромережі. Однак безризикова вартість енергії для автономних ЛЕС містить паливну складову, резервні потужності, та й мережева енергія має враховувати екологічні платежі (вуглецевий податок), вартість власне мережевої інфраструктури, соціальні стимули, тощо.

Іншим формулюванням задачі оптимізації може бути багатокритеріальний метод побудови оптимуму, в тому числі двокритеріальний, коли задано максимально допустимі значення вартості та ризику, а крива $\Psi\left(x_{i}\right)$ між цими значеннями $\epsilon$ зоною арбітражних рішень.

Крім зазначених, можуть бути інші критерії, наприклад максимальне впровадження певного виду генерації, мінімальне використання мереж чи традиційного палива, швидка окупність проекту, тощо. Слід зауважити, що до факторів, які впливають на можливості використання відновлюваних джерел енергії, відносяться як економічні та технологічні, так і екологічні, інституційні, соціальні [9]. Методом пошуку оптимальної конфігурації ЛЕС може бути як встановлення пріоритетності критеріїв (цільового програмування) чи вагових коефіцієнтів, так i інші способи розв'язання вирішення багатовимірних задач для пошуку паретооптимальних рішень. У випадку залежних від часу параметрів можна застосувати осереднені значення або розглядати динамічні моделі (рівняння Белмана і ін.). Крім того, при виборі кількості енергетичних модулів ми маємо справу 3 дискретним (цілочисельним) програмуванням.

Зазначимо, що критерій ризику також може мати вартісне вираження, наприклад вартість резервної (балансуючої) потужності та відповідної енергії, чи штрафні санкції за небаланс. В цьому випадку задача оптимізації стає однокритеріальною і $є$ класичною задачею лінійного програмування.

Виклад основного матеріалу. Собівартість електроенергії, отриманої з ВДЕ в комбінованій ЛЕС, визначається для кожного типу обладнання і певних кліматичних умов, тобто для конкрет- 
ного проекту може вважатися величиною детермінованою. Ризики проекту полягають в небезпеці втратити частину енергії чи не забезпечити потреби споживача. Зростання дисперсії як міри ризику відбувається при збільшенні частки випадкової складової, тобто ВДЕ. Зниження собівартості можливе, якщо ВДЕ заміщають більш вартісне джерело енергії. Однак при цьому може зрости частка втраченої енергії, що зменшує обсяг корисної (використаної) енергії при тих же витратах, тим самим збільшуючи ऑï собівартість. При використанні систем акумулювання енергії обсяг корисної енергії зберігається (за винятком втрат в акумуляторах), дисперсія зменшується, але зростає вартість обладнання, що також веде до росту собівартості енергії.

Отже, параметрами вектора стану ЛЕС $\Psi\left(x_{i}\right)$

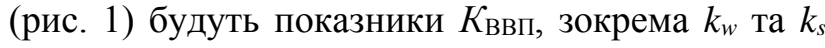
як сталі, а обсяг і пропорції ВДЕ $R, w$ вважаються змінними; змінною буде також потужність та ємність системи акумулювання енергії. Сталою може вважатись варіативність (СКВ), власне споживання енергіï $\sigma_{0}$, а результуюча варіативність небалансу енергії $\sigma_{\Sigma} \epsilon$ похідною від попередніх параметрів [10]. Допустимі величини ризику та собівартості енергії ( $\left.\sigma_{\max }, C_{\max }\right)$ відносяться до обмежень задачі оптимізації.

Якщо значення собівартості при деяких (тестових) умовах відомі, то вони за означенням обернено пропорційні до енергетичної

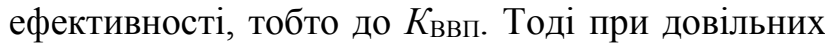

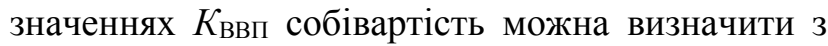
відповідної пропорції, наприклад для ВЕС: $C \boldsymbol{s}_{w}=C \boldsymbol{s}_{w}^{0} k_{w}^{0} / k_{w}$, де індексом «0» позначено тестові значення. При різних комбінаціях вітро-вої та сонячної генерації результуюча собівар-тість отриманої електроенергії буде залежати від їх

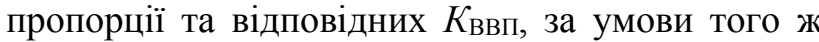
обладнання та фінансових умов, а саме:

$$
C \beta_{\Sigma}=\frac{C{ }^{0}{ }_{w} k_{w}^{0} w+C{ }_{s}^{0} k_{s}^{0}(1-w)}{k_{w} w+k_{s}(1-w)} .
$$

Тут собівартість як питомий показник не залежить від номінальної потужності обладнання (в загальному випадку враховуються особливості постійної та змінної складових вартості експлуатації). Отже, для довільної комбінації вітро-сонячних установок певного типу можна визначити результуючу собівартість електроенергії в різних погодних умовах (наприклад, для різних сезонів чи територій). При цьому варіативність (СКВ) генерації майже лінійно пропорційна номінальній потужності, тобто відносна СКВ $\left(C_{v}=\sigma / R\right)$ в даних умовах залежатиме лише від показника пропорції $w$, за винятком малих значень $R$, де більш помітним $€$ вплив варіацій споживання (див. табл. 1).

В табл.1 наведено приклад значень відносної варіативності (коефіцієнта варіації, віднесеного не до середньої, а до номінальної потужності) для локального споживача (населенного пункту, див. [11]), 3 урахуванням прогнозованого добового графіка.

На рис. 2 зображено множину станів ЛЕС $\Psi\left(x_{i}\right)$ при різних пропорціях ВДЕ в термінах кривої ризику-доходу Марковіца (в даному випадку їх аналогом $\epsilon$ варіативність та собівартість). Огинаюча знизу множини станів $€$ лінією можливих оптимальних значень. Використано дані квітня, коли значення $K_{\text {Ввп }}$ були близькі до середньорічних:

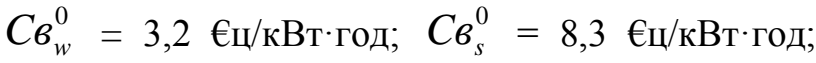
$k_{w}^{0}=0,24 ; k_{s}^{0}=0,14 ; k_{w}=0,44 ; k_{s}=0,19$.

Таблиця 1. Варіативність небалансу потужності $C_{v}$, в.о..

Table 1. Variability of power unbalance $C_{v}$, relative units.

\begin{tabular}{|l|r|r|r|r|r|r|r|}
\hline$R, \mathrm{\kappa BT}$ & \multicolumn{1}{l|}{1} & \multicolumn{1}{l|}{0,8} & \multicolumn{1}{l|}{0,6} & \multicolumn{1}{l|}{0,4} & \multicolumn{1}{l|}{0,3} & \multicolumn{1}{l|}{0,2} & \multicolumn{1}{c|}{0} \\
\hline 100 & 0,387 & 0,368 & 0,356 & 0,350 & 0,350 & 0,352 & 0,360 \\
\hline 200 & 0,263 & 0,232 & 0,209 & 0,197 & 0,195 & 0,197 & 0,210 \\
\hline 400 & 0,223 & 0,186 & 0,155 & 0,136 & 0,133 & 0,135 & 0,151 \\
\hline 800 & 0,215 & 0,174 & 0,140 & 0,118 & 0,113 & 0,115 & 0,133 \\
\hline 1200 & 0,214 & 0,173 & 0,137 & 0,114 & 0,110 & 0,111 & 0,130 \\
\hline
\end{tabular}




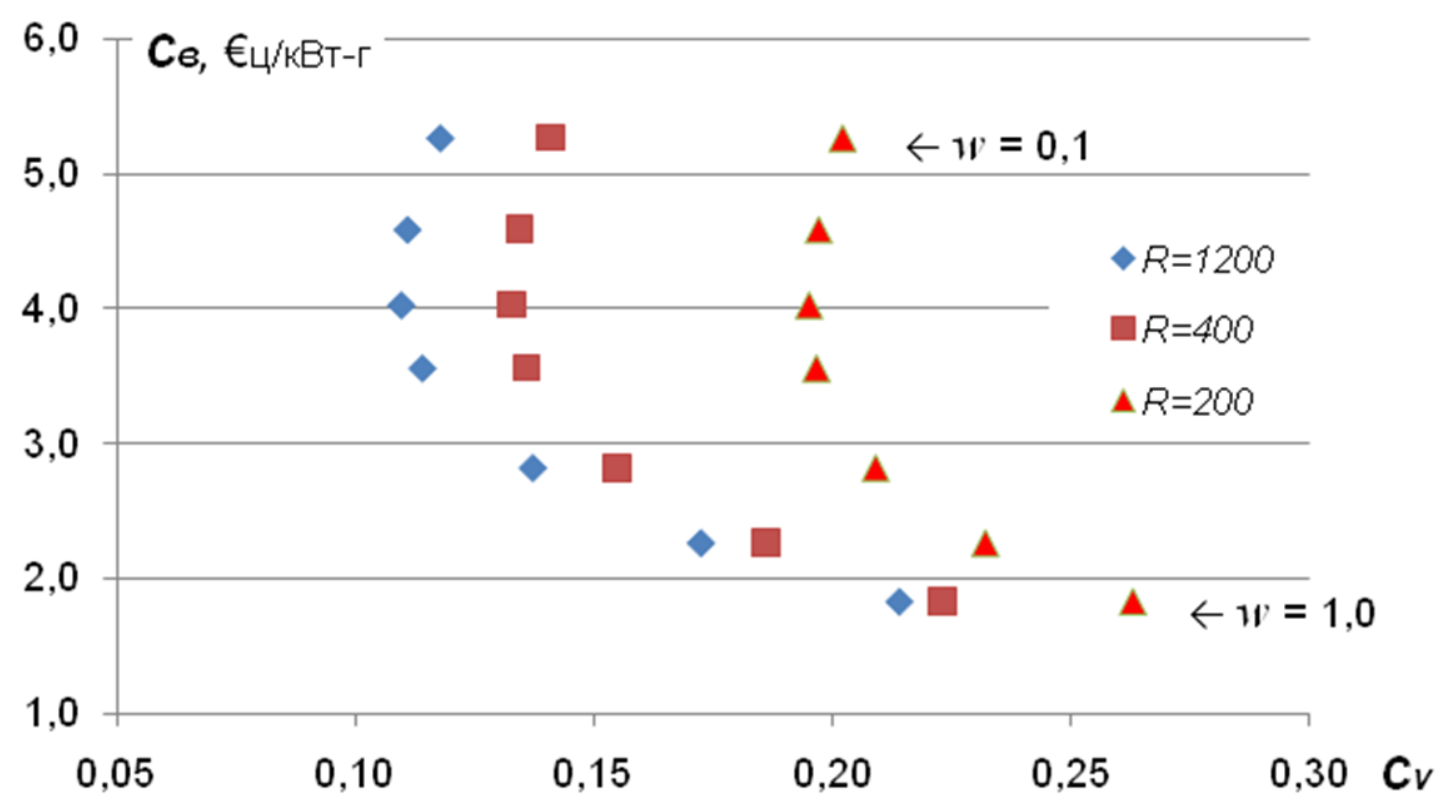

Рис. 2. Множина значень ризику-доходу для різних станів ЛЕС.

Fig. 2. Set of risk-income values for different states of LES.

Якщо за точку $C_{0}$ (див. рис. 1) взяти ординату мінімального значення варіативності $w=0,3$ (див. табл. 1), то відповідно до методу Дж.Тобіна точкою оптимуму має бути пропорція

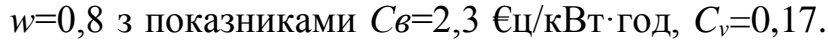
Таким $\epsilon$ результат оптимізації по критеріях собівартості та ризику для даного прикладу, в якому не встановлено обмежень на значення критеріїв. Наявність обмежень у вигляді $C_{8}<C B_{\max }$ чи $C_{v}<C_{v \max }$ приводить до появи арбітражної зони розв'язків.

Якщо в якості показника собівартості враховувати наявність акумулюючи потужностей у складі капітальних витрат, то собівартість зростатиме пропорційно вартості акумуляторів, а варіативність зменшуватиметься як обернено пропорційна потужності акумуляторів. Оскільки зазначені вартість та потужність пов'язані лінійно, то арбітражна зона $\Psi\left(x_{i}\right)$ буде близькою до прямої. Оптимальні значення будуть цілком визначатися заданими обмеженнями. Однак загальна потреба в акумуляторах визначатиметься як додатковою варіативністю при введенні ВДЕ до енергосисте- ми, так і заданою вимогою до надійності, а ці залежності є нелінійними (див. напр. табл. 1).

Вимоги щодо надійності можна сформулювати в термінах квантилів розподілу кумулятивної енергії небалансу, яка потребує акумулювання. Тут доцільним $€$ використання тези про нормальність розподілу небалансу. Тоді відповідні квантилі $\kappa_{\gamma} 3$ довірчою імовірністю $\gamma$ матимуть значення:

$|\kappa|_{0,8}=\kappa_{0,9}=1,29 ;|\kappa|_{0,9}=\kappa_{0,95}=1,64$;

$|\kappa|_{0,95}=\kappa_{0,975}=1,96 ;|\kappa|_{0,99}=\kappa_{0,995}=2,58$.

Візьмемо для прикладу дані щодо варіативності Дніпровської ЕС при значенні $R=2000$ МВт (такий рівень впровадження ВДЕ $\epsilon$ вагомим, але реальним). Потреби в акумулюванні визначаються через добавлене за рахунок ВДЕ СКВ кумулятивної енергії $\sigma_{\mathrm{K}}: \kappa_{\gamma}\left(\sigma_{\mathrm{K}}-\sigma_{\mathrm{K}}{ }^{0}\right)$, де індекс «0» стосується іманентної варіативності споживання при відсутності ВДЕ (в даному прикладі $\sigma_{K}{ }^{0}=570$ кВт.год).

Показники щодо добавленої за рахунок ВДЕ варіативності 3 різними довірчими рівнями наведено в табл. 2.

Таблиця 2. Моделювання $\sigma$ к для ДнЕС, добовий прогноз (МВт•год).

Table 2. Simulation of $\sigma_{\mathrm{K}}$ for DnES, daily forecast (MWh).

\begin{tabular}{|c|c|c|c|c|c|c|c|c|}
\hline$w$ & 1 & 0,8 & 0,6 & 0,4 & 0,3 & 0,2 & 0,1 & 0 \\
\hline$\gamma=0,80$ & 2012 & 1484 & 993 & 593 & 452 & 370 & 391 & 477 \\
\hline$\gamma=0,90$ & 2558 & 1886 & 1263 & 754 & 574 & 471 & 497 & 607 \\
\hline$\gamma=0,95$ & 3058 & 2254 & 1509 & 902 & 686 & 563 & 594 & 725 \\
\hline$\gamma=0,99$ & 4025 & 2967 & 1987 & 1187 & 903 & 740 & 782 & 955 \\
\hline
\end{tabular}


Для вартості капітальних вкладень у системи ВДЕ прийнято: для ВЕС $1200 € /$ КВ, для СЕС 700 $€ /$ кВт, для акумуляторних батарей (АКБ) приблизно $200 € /$ кВт.год (вартість за ємністю). Слід врахувати також, що термін експлуатації акумуляторів приблизно удвічі коротший порівняно 3 іншим обладнанням. Для забезпечення заданого рівня надійності (тобто довірчої імовірності) можна вирахувати вартість капіталовкладень у АКБ при заданому рівні ВДЕ. Оптимальну конфігурацію ВДЕ-АКБ можна обрати за методом «поверхні відгуку». Величину

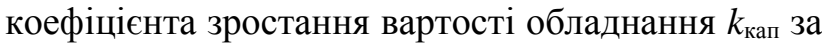
рахунок введення акумулюючих потужностей при різних рівнях надійності та конфігурації ВДЕ зображено на рис. 3.

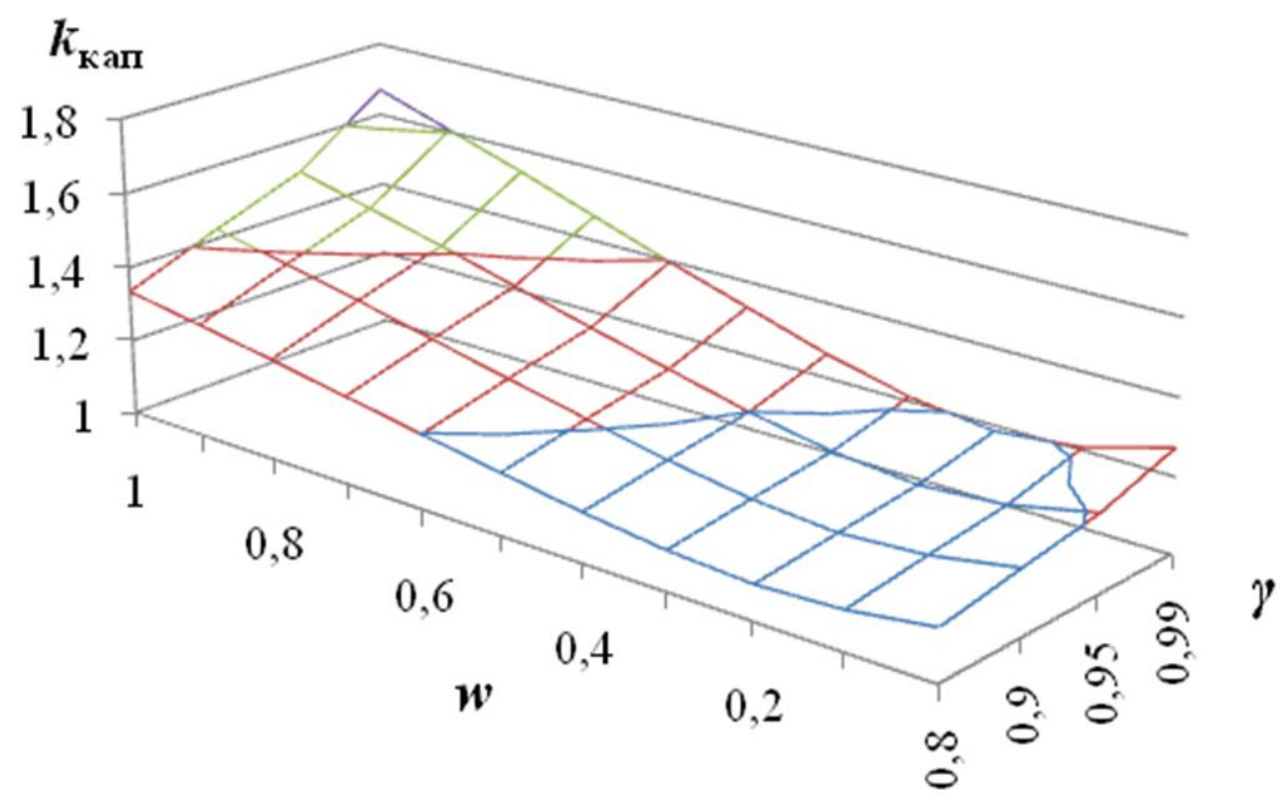

Рис. 3. Множина значень зростання вартості ВДЕ-АКБ для ДнЕС.

Fig. 3. Values of RES-ACB cost increasing for DnES.

В наведеному прикладі для регіональної енергосистеми потреба в ємності акумуляторів становила 10-15\% від добової продуктивності ВДЕ при забезпеченні високого рівня надійності (понад 95\% гарантованого забезпечення). Дані співвідношення можуть різнитися для різноманітних режимів поживання, пір року, типу обладнання. При цьому враховується можливість завчасного передбачення рівнів споживання та генерації та надійність роботи традиційних (керованих) джерел енергії.

Наведені приклади стосуються певних кліматичних умов, характеру споживання енергії, технічних та вартісних показників обладнання. Однак загальний характер поведінки параметрів, за якими можна оптимізувати енергосистему 3 ВДЕ, в безрозмірних параметрах має схожий вигляд незалежно від масштабу - як для окремого населеного пункту, так і для їх групи чи регіональної енергосистеми в цілому. Різниця полягатиме в конкретних числових показниках, що застосовуються в математичній моделі, та в результуючих співвідношеннях.
Висновки. Метою оптимізації можуть слугувати як технічні параметри (допустимі значення небалансу потужності відповідно до вимог забезпечення частоти та напруги в мережі певної енергосистеми, чи показники надійності та рівнів втрат при забезпечені конкретного споживача), так і економічні - загальна вартість проекту впровадження ВДЕ, собівартість отриманої енергії, тощо. До економічних показників можна віднести і рівень заміщення традиційної енергетики відновлюваною, якщо мова йде про екологічні вимоги та відповідні компенсаційні виплати.

Оскільки дані висновки грунтуються як на імітаційному моделюванні, так і на безпосередній перевірці шляхом реаналізу статистичних даних як сполучної ланки між спостереженнями та моделюванням, можна вважати достатньо адекватною запропоновані математичні моделі представлення випадкових процесів, що описують балансування споживання та генерації електроенергії 3 використанням вітрової та сонячної енергетики. Перелік задач, які можуть 
вирішуватися в рамках даних моделей, стосується переважно питань оптимізації енергосистем на базі відновлюваної енергетики, оцінки результатів експлуатації таких систем, розрахунку очікуваних показників при постановці задач енергопостачання та передпроектних досліджень. Головною метою має бути забезпечення надійності постачання та якості енергії, а також енергетичної та економічної ефективності.

Стаття підготовлена в рамках виконання проектів науково-технічних робіт та цільових програм Національної академії наук України: «Комплекс-М», «Комплекс-3» (КПКВК 6541030), «Енергодім» (КПКВК 6541230).

1. Okinda V.O. , Odero N.A. A Review of Techniques In Optimal Sizing of Hybrid Renewable Energy Systems. IJRET. International Journal of Research in Engineering and Technology. 2015. Vol. 04, Is.11. Pp. 153-163.

2. Tran T.D., Smith A.D. Stochastic Optimization for Integration of Renewable Energy Technologies in District Energy Systems for Cost-Effective Use. Energies 2019. Vol. 12(3). 533 p. doi: 10.3390/en12030533.

3. Кузнеиов Н.П., Смертюк В.Н., Лысенко О.В., Нестерчук Д.Н., Адамова С.В. Оптимизация соотношения мощностей ветровых и солнечных электростанций. Problemele energeticii regionale. Kishinev. 2018. № 3(38). C. 127-140. doi:10.5281/zenodo.2222378.

4. Lezhniuk P.D., Komar V.O., Sobchuk D.S. Method for Determination of Optimal Installed Capacity of Renewable Sources of Energy by the Criterion of Minimum Losses of Active Power in Distribution System. Energy and Power Engineering. (Scientific Research Publishing Inc.). 2014. № 6. Pp. 37-46.

5. Велькин В.И. Методология расчета комплексных систем ВИЭ для использования на автономных объектах. Монография. Екатеринбург. УрФУ. 2015. $226 \mathrm{c.}$

6. Lezhniuk P., Komar V., Kravchuk S., Sobchuk D. Mathematical modeling of operation quality of electric grid with renewable sources of electric energy. MEES IEEE International conference on modern electrical and energy systems. 2017. Pp. 324-327.

7. Tobin J. The Teory of Portfolio Selection. The Teory of Interest Rate. London. Macmillan. 1965. Pp. 3-51.

8. Markowitz H.M. Portfolio selection. Journal of Finance.1952. № 7(1). Pp. 77-91.

9. Тащеєв Ю.В., Ковальов А.І. Формування економічного механізму використання відновлюваних джерел енергії на підприємствах. Науковий вісник Одеського національного економічного університету. 2018. № 9(261). С. 62-83.

10. Kuznietsov M., Vyshnevska Y., Brazhnyk I., Melnyk $O$. Modeling of the Generation-Consumption Imbalance in the Heterogeneous Energy Systems with Renewable Energy Sources. IEEE 6th International
Confe-rence on Energy Smart Systems (ESS). conferencepaper. 2019. Pp.196-200. doi: 10.1109/ess.2019.8764189.

11. Лисенко O.B. Оцінка випадкових властивостей рівнів споживання електроенергії. Відновлювана енергетика. 2018. № 1. С. 26-35.

\section{REFERENCES}

1. Okinda V.O. , Odero N.A. A Review of Techniques In Optimal Sizing of Hybrid Renewable Energy Systems. IJRET. International Journal of Research in Engineering and Technology. 2015. Vol. 04, Is.11. Pp. 153-163. [in English].

2. Tran T.D., Smith A.D. Stochastic Optimization for Integration of Renewable Energy Technologies in District Energy Systems for Cost-Effective Use. Energies 2019. Vol. 12(3). 533 p. doi: 10.3390/en12030533. [in English].

3. Kuznietsov N., Smertiuk V., Lysenko O., Nesterchuk D., Adamova S. Optimizing the Ratio of Wind and Solar Power Stations. Problemele energeticii regionale. [Optimizatsiya sootnosheniya moshchnostey vetrovykh i solnechnykh elektrostantsiy] Kishinev. 2018. No. 3(38). Pp.127-140. doi: 10.5281/zenodo.2222378. [in Russian].

4. Lezhniuk P.D., Komar V.O., Sobchuk D.S. Method for Determination of Optimal Installed Capacity of Renewable Sources of Energy by the Criterion of Minimum Losses of Active Power in Distribution System. Energy and Power Engineering. (Scientific Research Publishing Inc.). 2014. № 6. Pp. 37-46. [in English].

5. Velkin $V$. Metodologiia rascheta kompleksnykh sistem VIE dlia ispolzovaniia na avtonomnykh obieektakh: monografiia. [Methodology for calculating integrated renewable energy systems for use on autonomous facilities: monograph]. Yekaterinburg. UrFU. 2015. 226 p. [in Russian].

6. Lezhniuk P., Komar V., Kravchuk S., Sobchuk D. Mathematical modeling of operation quality of electric grid with renewable sources of electric energy. MEES. IEEE International conference on modern electrical and energy systems. 2017. Pp. 324-327. [in English].

7. Tobin J. The Teory of Portfolio Selection. The Teory of Interest Rate. London. Macmillan. 1965. Pp. 351. [in English].

8. Markowitz H.M. Portfolio selection. Journal of Finance.1952. № 7(1). Pp. 77-91. [in English].

9. Tashcheiev Yu., Kovalov A. Formuvannia ekonomichnoho mekhanizmu vykorystannia vidnovliuvanykh dzherel enerhii na pidpryiemstvakh. Naukovyi Visnyk Odeskoho Natsionalnoho Ekonomichnoho Universytetu. [Formation of an economic mechanism for the use of renewable energy sources at enterprises. Scientific Bulletin of the Odessa National Economic University]. 2018. No. 9(261). Pp. 62-83. [in Ukrainian].

10. 10. Kuznietsov M., Vyshnevska Y., Brazhnyk I., Melnyk $O$. Modeling of the Generation-Consumption Imbalance in the Heterogeneous Energy Systems with Renewable Energy Sources. IEEE 6th International Confe-rence on Energy Smart Systems (ESS). conference- 
paper. 2019. Pp.196-200. doi: 10.1109/ess.2019.8764189. [in English].

11. Lysenko $O$. Otsinka vypadkovykh vlastyvostei rivniv spozhyvannia elektroenerhii. [Estimation of random properties of electricity consumptionlevels]. Vidnovluvana Energetika, 2018. No. 1(52). Pp. 26-35. URL: http://ve.org.ua/index.php/journal/article/view/8 [in Ukrainian].

\section{ЗАДАЧИ ОПТИМИЗАЦИИ КОМБИНИРОВАННЫХ ЭНЕРГЕТИЧЕСКИХ СИСТЕМ ПО ЭКОНОМИЧЕСКИМ КРИТЕРИЯМ}

М.П. Кузнецов ${ }^{1}$, докт. техн. наук, О.В. Лисенко ${ }^{2}$, канд. техн. наук, А.А. Мельник ${ }^{3}$, аспирант.

${ }^{1}$ Институт возобновляемой энергетики НАН Украины 02094, ул. Г.Хоткевича, 20А, г. Киев, Украина.

2Таврический государственный агротехнологический университет

72310, ул. Б. Хмельницкого, 18, г.Мелитополь, Украина.

${ }^{3}$ Национальный технический университет Украины «Киевский политехнический институт им.И.Сикорского». 03056, пр-т. Победы, 37, г. Киев, Украина.

Целью данной работь является решение многокритериальной задачи оптимизации для локальной энергосистемь (ЛЭС) с возобновляемыли источниками энергии (ВИЭ). В традиционной энергетике основной задачей является минимизация себестоимости электроэнергии, но при применении возобновляемых источников энергии на первый план выступает надежность энергообеспечения, учитывая изменчивую природу генерации таких ВИЭ, как ветровые $и$ солнечные электростанции. Предметом исследования является установление пропоричи ветровой, солнечной генерации и систем хранения энергии, обеспечивающих заданные требования к надежности при минимальной себестоимости электроэнергии. Особенностью данного исследования является учет неопределенности режимов потребления и использования возобновляемых источников энергии. Методы исследования включают применение статистического подхода и имитационное генерирования случайных прочессов для стохастической оптимизации расходов. В качестве исходных данных используются исторические (статистические) данные о потреблении энергии и климатических факторах, влияюших на генерацию. Для показателей надежности существенными являются не только средние значения, но и показатели вариации (дисперсия, плотность распределения, предельные отклонения). Неопределенность, связанная с возобновляемыми источниками, может привести $к$ неопределенности эксплуатациинных расходов. Дополнительным источником неопределенности является переменный характер потребления электроэнергии. Риски проекта заключаются в опасности потерять часть энергии или не обеспечить потребности потребителя. Наличие аккумуляторов энергии снижает риски, но увеличивает стоимость проекта. Результатом исследования является способ оптимизации такой системь. Риск можно определить, как дисперсию случайной составляющей, тогда целевыми функичями будут себестоимость энергии $и$ стандартное отклонение небаланса мощнности. Для поиска оптимального решения при двух условиях применена математическая модель текущуего состояния энергосистемь с разнотипными ВИЭ и системой аккумулирования.Огибающая множества состояний является линией возможных оптимальных значений. Ограничениями задачи есть требования к надежности, например, доверительная вероятность небаланса генерации и потребления. Библ. 11, табл. 2, рис. 3.

Ключевые слова: возобновляемые источники энергии, локальная энергосистема, надежность, себестоимость, случайный процесс, оптимизация. 